\title{
The ARPANET Into the Internet: A Tale of Two Networks
}

\author{
Noel Packard \\ Correspondence: Noel Packard, Department of Media, Film and Television, University of Auckland, New Zealand.
}

Received: Mar. 23, 2020

doi:10.11114/smc.v8i1.4783

\author{
Accepted: Apr. 15, 2020 \\ Online Published: Apr. 24, 2020 \\ URL: https://doi.org/10.11114/smc.v8i1.4783
}

\begin{abstract}
The Internet is a split civilian and military entity in physical and social construction. Investigating this split entity in all its manifestations is an important venture, but this study explores the split social construction of the ARPANET's reported history. ARPANET/Internet literature shows a division between literature that does and does not include the history of the intelligence communities (IC) working relationship with the pre-privatized ARPANET. Two different genres of literature are discussed, charted in a Table and compared to aspects of the ARPANET's known and reported developmental and privatization history. Different origin stories are discussed in a general way; then a pattern in the literature is explored, namely, how illegally and libelous spy data gathered in 1960s intelligence community (IC) operations and processed through the pre-privatized ARPANET, is acknowledged in indirect or second-hand ways, when ARPA demonstrated feasibility of the ARPANET ; while after privatization the literature acknowledges IC spying through the commercialized Internet in firsthand and direct ways. The study examines how earlier and contemporary literature continues contesting the role that 1960s IC spy data played in demonstrating the feasibility of the ARPANET; a prerequisite test for the privatization of the ARPANET. Findings indicate ARPANET histories have excluded direct reporting about how ARPA and the IC demonstrated ARPANET's feasibility prior to privatization. The conclusion is that understanding history about how ARPA and the IC demonstrated ARPANET's feasibility, makes it easier to comprehend reports about how the Internet serves counterinsurgency purposes. The study confirms ongoing debates about the social construction of Internet history.
\end{abstract}

Keywords: internet, intelligence community, counterinsurgency, informational infrastructure, ARPANET feasibility demonstration

\section{Introduction}

\subsection{Introducing ARPANET's Split History and Literature Trail}

Clearly there isn't one official "creation story" for the ARPANET turned Internet; there are different versions of ARPANET's creation story, and some versions are better known than others. This body of literature is split, much like the historical development of the ARPANET is split, between history that is secret and public. Some history acknowledges the working relationship between the Intelligence Community (IC), and the ARPANET and some history overlooks it. Table 1 is a sampling of ARPANET related literature divided into pre- and post-privatization literature and into two literature genres, Creation Story \#1 and Creation Story \#2. This Table helps chart a division in the literature trail of the ARPANET/Internet history. Table 1 will be discussed in more detail following a discussion that sets historical context regarding how ARPANET research was funded and how ARPA operated during the pivotal decade of the 1970s. This was the decade when the IC was under intense government and public scrutiny for abusive 1960s spy operations against Americans, while ARPA was making strides in building interactive computers and data-banks, including the ARPANET, which was privatized in 1995, after it demonstrated its' feasibility.

\subsection{Setting Context: Forging ARPANET's Spilt History and Literature Trail}

ARPANET is a complex of interactive computers built by Advanced Research Project Agency (ARPA), later re-named Defense Advanced Research Project Agency (DARPA), which today serves as the Internet. According to "Why the Arpanet Was Built"'(2011) by Stephen J. Lukasik, who was DARPA's Director in the early 1970s, ARPA's first concerns were "Presidential Issues" or "assignments coming to it directly as a result of White House concerns" one of which was "counterinsurgency and unconventional warfare" (6). In the 1960s President Kennedy's views of military involvement in Southeast Asia fell in line with military intelligence agent, William Godel, who had a vision of counterinsurgency warfare to fight Communism (US Senate 1976a, 120). Kennedy legislated funding for Godel's counterinsurgency research in Vietnam; a fascinating history resurrected by authors: Paul Edwards (1996), Anne Jacobsen (2015), Sharon Weinberger (2017) and Yasha Levine (2018). Godel's R\&D used research about the Vietcong, gathered by Simulmatics Corporation. 
Simulmatics, was a company created by Ithiel de Sola Pool (an MIT associate to famous interactive computing scientist J.C. Licklider). It gathered survey information about what motivated the Vietcong, for use in developing computer software programs to predict and pre-empt Vietcong actions (Rohde 2011). Witting of it or not, Licklider, Pool and Godel were inventing the early forms of computerized, predictive, artificial intelligence which underpin ARPANET counterinsurgency capability (Edwards, 1996; Levine 2018,1-25, 64-7, 51-3; Weinberger 2017). Edward Lansdale the "master practitioner of psychological warfare" (McCoy 2009, 377-8, 382-3; Wilford 2008) oversaw Godel's counterinsurgency research operations in Vietnam with code names: Igloo White; AGILE; and the Phoenix program of assassination. ARPA also contracted J.C. Licklider at MIT Lincoln Laboratory in Cambridge, Mass., to be Director of Command and Control; renamed Information Processing Techniques Office (IPTO) in 1964. Licklider (or Lick) had a vision for "interactive" computing. Lick's leadership creating interactive computing for the military, IC and Pentagon, pushed Godel's counterinsurgency R\&D into the background and publicly re-constructed the ARPANET as a visionary, neutral, communication infrastructure, rather than a counterinsurgency weapon (Jacobsen 2015, 238-9). Thus, the ARPANET was born with a "split personality" since part of its' creation story roots to counterinsurgency warfare research and part to communication and interactive computing research.

According to Lukasik's testimony for the Subcommittee of the Committee on Appropriations (US 1972, 732-3) "service mission assignments" occurred when an ARPA invention, like the ARPANET, was assigned to service a particular agency or department, such as the Defense Communication Agency (DCA) or the National Security Agency (NSA). After an invention had undergone feasibility demonstrations or essentially had gone through a dress rehearsal performance of what it was capable of, government agencies or companies would be paired with the invention for service missions. ARPANET was arguably the most expensive invention in history. Shah and Kesan report, "The U.S. government spent approximately $\$ 160$ million in direct subsidies over an 8- year period to fund the backbone network. However, the government likely spent 10 times this amount ..." (2007, 93). IPTO budgets were justified in terms of fighting Communism abroad or domestically, through methods such as computer assisted counterinsurgency warfare, which included data processing of societal data, collected by human informants (Theoharis 1985) and contracted social scientists (Rhode 2011, 2013a) or from experimental electronic databanks developed by the military (US Senate 1976c, 500-3).

ARPA's Command and Control Division's impressive achievements became marketing tools for ARPA to solicit Congressional funding (Norberg \& O’Neill, 1996, 63). In 1968, however, Senator Mansfield, fearing the CIA was taking advantage of universities for R\&D, attached a rider to a Department of Defense (DoD) military authorization bill (PL 91121) for FY 1970, mandating funds for university research have a "relationship to a specific military function or operation" (Norberg \& O'Neill, 1996, 36). The rider was short lived or ignored by ARPA since according to. Lukasik's testimony, DARPA did R\&D on some projects before they had a mission assigned to them. This was because of a lack of a "clear charter" (DOD 1972, 732) or lack of a particular service (Army, Navy, IC) willing to put an invention into mission service before seeing it demonstrate its feasibility and receiving advice from DARPA as to appropriate service missions.

Lukasik testified ARPA did "high-risk/high-payoff” (DOD 1972, 729) R\&D projects to protect national security against "technological surprise" (734) and this included "feasibility demonstrations, undertaken prior to the assignment of a mission to a specific military service" (729). To demonstrate how this budgeting and mission assignment process appears to have worked, consider a proposal in the 1972 DARPA budget request hearings of March 14. DARPA solicited a "Human Resources Research" proposal request for $\$ 7.6$ million dollars; just one project in a budget proposal of $\$ 226,727,000$ for fiscal year 1973. shared among: ARPA, Defense Communication Agency (DCA); Defense Special Projects Group; Defense Nuclear Agency; Defense Intelligence Agency (DIA); National Security Agency (NSA); Defense Supply Agency; and OSD/JCS technical support (DOD 1972, 725, 727, 766). Within the Human Resources Research program was a project titled "Analysis and Modeling of Complex Systems" (767) with a projected budget of $\$ 1,675,000$, to be undertaken jointly by Massachusetts Institute of Technology (MIT) and sub contactor Harvard University. A descriptive summary of this project reads:

The objective of this project is to develop an advanced, computer based analytical capability for application to Defense problems requiring for their solution the simultaneous management and control of a large number of behavioral factors as well as the manipulation of extremely large masses of data. In addition to analytical methods, the project focuses on the development of a computer facility and associated programing techniques, which will permit the sharing of data and methods among a community of scientists and Defense personnel who need not be computer experts to use the system effectively. Examples of Defense Department applications for which this advanced capability will be useful include: (a) the management and rapid analysis of masses of intelligence data to discern trends and significant events; (b) simulation and experimental assessment of the operational dynamics of large command and control systems; (c) comprehensive analysis of the diverse factors which bear on the effective operation and management of the DoD personnel force; (d) quantitative assessment of the numerous 
factors bearing on strategic defense postures to enhance the capability to forecast and prepare for possible armed conflict. (US DOD 1972, 768)

This summary fits the description of Licklider's Project CAMBRIDGE (or Project CAM), which replaced the failed Project CAMELOT (both projects entailed collecting social science data on civilian populations) (Levine 2018, 62-71; Rohde 2011, 2013b). Project CAMELOT failed partly because proposed data collection was to be undertaken in countries outside the US, such as Vietnam and Chile (Horowitz, 1974; Levine 2018; Rohde 2011, 2013b), but data for Project CAM was collected in the US. Development of these projects fell under IPTO where Lick served as Director from 1962-4 and from 1974-5 (Norberg \& O'Neill, 1996, 16). Lick's pioneering of interactive computing, which he coined the "Great Intergalactic Network" was legendary among a growing circle of famous universities, labs and think tanks, as authors across the academic spectrum report (Levine 2018; Lukasik 2011; Moschovitis, Poole, Schuyler \& Senft 1999, 48-9; Naughton 2001; Norberg \& O’Neill 1996; Novak 2015; Salus 1995, 6-7; Waldrop 2001; Weinberger 2017). When Licklider became Director of IPTO in 1962 he asked the National Security Agency (NSA) if they were developing interactive computers. The response was, in Lick's words "the NSA, they really needed what I wanted" (Levine 2018, 50-9). IPTO set about developing computers to serve the needs of the NSA and DIA, which entailed processing, storing and sharing, "extremely large masses of data" (DOD 1972, 768). Where did the "masses of data" come from?

According to Director Lukasik, ARPA's first concerns were "Presidential Issues" (Lukasik 2011, 6). Masses of data were collected in response to Presidents Johnson and Nixon urging the IC to find the foreign Communist agitators who were agitating against the Vietnam War (Donner 1981, 259; Halperin, Berman, Borosage \& Marwick 1976, 135-7; US Senate 1976b, 96-104). The IC ran hundreds of spy operations in the 1960s to gather personal information about dissidents they called Communists or "New Left" (US Senate 1976 b, 17, 72-4). The FBI's COINTELPRO and the CIA's CHAOS spy operations ran simultaneously in the US beginning in 1966, to name only two spy operations among hundreds (Churchill and Vander Wall, 1990;Johnson 1990; Keller 1989, Table 5.3, 166-174; Pyle 1974: Rowan 1978; US Senate 1976, a, b, c). IC agents collected spy data in hard copy, transferring it to computers to create electronic data (US Senate 1976c, 50053). The operations grew continuously and became aggressive and libelous; even Senators agreed they were targets of military spy operations (Blum 1972). In March 1971, a break-in at a Media, Pennsylvania, FBI field office, by anti-war protestors looking for military draft documents, uncovered over 1,000 pages of COINTELPRO documents confirming FBI spy operations were acting beyond the law (Keller 1989, 115-7). Responding to public outcry over reports about illegal IC spying and electronic data-banking of personal information the President, the Senate and Congress mobilized commissions and committees to study how the IC was operating lawlessly and beyond the Constitution (US 1971; US Senate 1973; US Commission 1975 ;U.S. Senate 1976; U.S. Senate 1976 a-f). In the "Selected Bibliography" of Donner's Age of Surveillance there are over 80 government publications listed relating to government surveillance and IC abuse within the Cold War era (1981, 528-32) and corroborated by The Lawless State: The Crimes of the US Intelligence Agencies (Halperin et al. 1976).

Processing intelligence gathered by 1960s spy operations or contracted social scientists, rationalized and justified funding ARPA/IPTO's projects, but when Robert Sproull became Director of ARPA in 1963 he almost terminated Lick's IPTO budget (Weinberger 2017, 120). Lick impressed Sproull with feasibility demonstrations of interactive computer projects at nodes (computers located in university labs). Such feasibility demonstrations proved the ARPANET's effectiveness and secured continued funding. This is how ARPA funded and managed high-risk, high-payoff projects. As the invention demonstrated its feasibility, ARPA managers would advise the Director of Defense Research and Engineering as to what service mission the invention (or project) was suited for (US DOD 1972, 729, 733-4). When Lukasik requested funding for "Analysis and Modeling of Complex Systems" for MIT and Harvard, it was likely part of Project CAMBRIDGE (Project CAM), which replaced Project CAMELOT. NBC reporter Ford Rowan described Project CAMELOT as a "cleaver blend of sociology and espionage" $(1978,216)$. Project CAM continued Project CAMELOT'S research into how computers, behavioral science and social data could be combined to develop forecasting tools to aid the military in countering civilian unrest. As Rowan explained in TechnoSpies, (1978) the research leads to the development of computer systems, which predict people's behavior and "pinpoint those who merit additional surveillance or harsher methods of control" (1978, 217). A similar argument has been made about Godel's Phoenix program of assassination R\&D contributing to the creation of PROMIS software (of Inslaw case fame) which tracks any data-banked information (Thomas and Keith 1996). Project CAM or similar projects, could have used social science data processed by contracted academics in Vietnam and/or data from US based IC political spying operation to demonstrate ARPANET's interactive computing and counterinsurgency feasibility (Donner 1981; Halperin et. al. 1976; Keller 1989, Table 5.3, 166-74; Rohde 2011, 2013; Rosenfeld 2013; US Senate 1973; US Senate 1976c, 500-53).

In the 1970s the public was alerted to the military's spy operations and data-banking by whistleblower, ex-intelligence Captain Christopher Pyle's article titled “CONUS Intelligence: The Army Watches Civilian Politics” (1970). The article 
generated public outcries regarding illegal surveillance and infiltration of civilian political, activist, educational, cultural, ethic, and religious groups. Nearly every group in the country, from church to political groups were subject to surveillance and infiltration by IC agents (Johnson 1990; Keller 1989, 166-74; US Senate 1976 c, 87, 441-7, 487-8, 500-54). Lukasik made his 1972 testimony after Pyle's 1970 whistleblowing about the military's CONUS databank and amongst the 80plus government committee studies and hearings, investigating IC abuses, between 1970 and 1976 (Donner 1981, 52832). In contrast History of the Internet: A Chronology, 1843 to the Present (1999) (listed in Creation Story \#1 literature in Table 1) side-steps and marginalizes this IC history (Moschovitis et. al 1999, 68).

The Defense Communications Agency (DCA) received ARPANET for mission service in 1975 a few weeks after the Senate Committee on the Judiciary published a report "Surveillance Technology" (US Senate 1976) in response to public concerns that military spy files were not being destroyed, as the military had been mandated to do in 1970; instead they were being copied and distributed to different data banks within the IC (French 1975, 1; Levine 2018, 90, 296n51; Sandler \& McNamee 1975, 1; US Senate 1973, 6). In 1988 Government Computer News reported ARPA was replacing ARPANET with an improved high-speed Defense Research Internet (DRI) grafted onto the ARPNET (Munro 1988). The original ARPANET backbone was transformed into the DRI and split with the National Science Foundation (NSF), which oversaw the privatization of the commercial side of the ARPANET. The DOD divided the taxpayer subsidized MILNET and communications lines "shared among several agencies", from the ARPANET for civilian networks, which is "leased" to taxpayers (Munro 1988). Abbate (2000) reports on how the NSF planned to incorporate, privatize and popularize the ARPANET (2000, 181-208). By 1988 the ARPANET became DRI and NSF networks. By 1990 ARPANET was decommissioned from the military and in 1995 the World Wide Web was activated. The Telecommunications Deregulation Act of 1995 heralded the largest sell off of public utility communications property in history. In 1996 the world witnessed the four largest corporate mergers of communications companies in history (Jensen 1997, 320-1, 324-5; McChesney 1996). In 1996 the Internet entered the commercial market in the hands of a few ex-military-contractor (men only) run companies who paid virtually nothing for it (nor had to competitively bid on the property). The world's most expensive counterinsurgency weapon was privatized into an informational infrastructure, paid for with millions of taxpayer dollars, in a completely deregulated marketplace without a single company, country or government in charge of regulating or overseeing it (Jensen 1997; McChesney 1996;Schiller 1999; Shah \& Kesan, 2007). Throughout the changes in its' mission service from ARPA to DCA to DRI to NSF to Internet, the ARPANET, turned Internet, has remained a "split entity" in function and social, as well as physical, construction. Now the study examines a sampling of literature that reflects this split social construction of the ARPANET's reported history.

\section{Method}

\subsection{Introduction to Table 1}

The literature listed below in Table1 is divided between pre-privatized and post-privatized ARPANET literature, with the dividing date at 1995. The upper area of the Table corresponds to this pre-privatized period during which ARPA was demonstrating the feasibility of the ARPANET in preparation for privatization. The phrase "Pre-privatized ARPANET \& feasibility demonstration stage" is blanket terminology for the military and IC networks that formed the original ARPANET "backbone" or root, prior to privatization. For example, MILNET was the military's network, which was part of ARPANET, while the NSA had a node on the ARAPANET, and so on, as Novak illustrates (2015). "Post-privatized Internet" is blanket terminology for the civilian, privatized and commercialized side of the ARPANET turned Internet, which is paid for by taxpayers/consumers. The literature is divided again between Creation Story \#1 in the left column and Creation Story \#2 literature in the right column. Creation Story \#1 literature lists a sampling of ARPANET/Internet literature that does not acknowledge the IC working relationships with the ARPANET before privatization. Creation Story \#2 literature lists a sampling of ARPANET/Internet literature that does acknowledge IC working relationships with the ARPANET, but the acknowledgment appears as second-hand information in the pre-privatization, pre-9/11 literature, while in post-privatized, post 9/11, literature the acknowledgment is first-hand and direct. These Columns are marked to indicate "9/11 2001" and "2013 Snowden". Creation Stories \#1 and \#2 are discussed in a general way; then a pattern in the literature is explored, specifically, how spy data gathered in 1960s intelligence community (IC) operations and processed through ARPANET, is acknowledged in indirect or second-hand ways in pre-privatized ARPANET literature, while after the Internet privatization, literature acknowledges similar IC spying through the Internet in firsthand and direct ways. Creation Story \#1 literature demonstrates a different pattern, overlooking the IC history and shifting from optimistic to darker views of the Internet post Snowden. In this way the social construction of ARPANET history continues to be divided between two literature genres. The following sections comparatively analyze aspects of pre-privatized and postprivatized Creation Story \#1 and \#2 literature and Conclusions follow after. 
FIGURE 1. Two literary genres regarding history of the ARPANET into Internet

Creation Story \#1 is without regard to intelligence community (IC) working relationship with ARPANET/Internet.

Creation Story \#2 is with regard to IC working relationship to ARPANET/ Internet and/or the feasibility demonstration stage of the pre-privatized ARPANET.

\begin{tabular}{|c|c|}
\hline Creation Story \#1 & Creation Story \#2 \\
\hline $\begin{array}{l}\text { Pre-Privatized Arpanet \& feasibility demo stage } \\
\text { 1948- Cybernetics: Or Control and Communication in the } \\
\text { Animal and the Machine- Wiener } \\
\text { 1960- "Man-Computer Symbiosis,"- Licklider } \\
1971 \text { Whole Earth Catalog- Brand }\end{array}$ & $\begin{array}{l}1968 \text { The Cambridge Project: Social Science for Social } \\
\text { Control-SDS } \\
\text { 1971- Schlesinger Report } \\
1975 \text { Report to the President by the Commission on CIA } \\
\text { Activities- Rockefeller Report } \\
\text { 1976 The Lawless State - Halperin et al. } \\
\text { 1976 U.S. Senate. (Church Committee Reports) } \\
\text { 1978. Techno Spies- Rowland } \\
\text { 1981 The Age of Surveillance- Donner } \\
\text { 1990-Agents of Repression-Churchill \& VanderWall }\end{array}$ \\
\hline $\begin{array}{l}\text { Post-Privatized Internet } \\
1995 \text { Casting the Net: From ARPANET to INTERNET } \\
\text { and beyond-Salus } \\
1996 \text { When Wizards Stay Up Late-Hafner \& Lyons } \\
1996 \text { Transforming Computer Technology Information } \\
\text { Processing for the Pentagon, Norberg \& O'Neill } \\
1996 \text { Digital Capitalism-Schiller } \\
1999 \text { History of the Internet- Moschovitis et al. } \\
2000 \text { Inventing the Internet-Abbate } \\
\text { 9/11 2001 } \\
\text { 2001 The Dream Machine: J.C.R. Licklider Waldrop } \\
2001 \text { A Brief History of the Future: The Origins of the } \\
\text { Internet-Naughton } \\
\text { 2002 Ruling the Root-Mueller } \\
2003 \text { What the Dormouse Said: How the Sixties Counter- } \\
\text { Culture Shaped the Personal Computer Industry-Markoff } \\
2006 \text { From Counterculture to Cyberculture-Turner } \\
\text { 2013 Snowden } \\
\text { 2019. The Age of Surveillance Capitalism-Zuboff } \\
\text { 2017 The Imagineer's of War- Weinberger } \\
\end{array}$ & $\begin{array}{l}\text { 9/11 } 2001 \\
2002 \text { Machine Dreams Mirowski } \\
2005 \text { No Place to Hide- O'Harrow } \\
2008 \text { Spies for Hire: The Secret World of } \\
\text { Intelligence- Shorrock } \\
2009 \text { Policing America's Empire McCoy } \\
2009 \text { The Shadow Factory: The Ultra-Secret NSA from } 9 / 11 \\
\text { to the Eavesdropping on America. Bamford } \\
2010 \text { The Watchers: The Rise of America's Surveillance } \\
\text { State-Harris } \\
\text { 2013 Snowden } \\
\text { 2013-Armed with Expertise-Rohde } \\
\text { 2014 No place to hide: Edward Snowden, The NSA, and The } \\
\text { U.S. Surveillance State-Greenwald } \\
\text { 2014@ WAR: The Rise of the Military-Internet Complex- } \\
\text { Harris } \\
\text { 2015 The Pentagon's Brain-Jacobsen } \\
\text { 2018 Surveillance Valley: The Secret Military History of the } \\
\text { Internet-Levine } \\
\text { 2019 Permanent Record-Snowden }\end{array}$ \\
\hline
\end{tabular}

\subsection{Comparing Pre-Privatization Creation Story \#1 and \#2 Literature}

Generally, Creation Story \#1 literature maintains ARPANET/Internet is a military funded communication system designed to survive nuclear attacks, built by contracted civilian scientists, used for academic purposes and then expanded for the benefit of society. The literature usually focuses on the technical achievements of scientists and engineers and their ties to academic institutions and laboratories. This is the ARPANET history most people have some vague understanding of. It is an account that leaves out the relationship between the ARPANET and the IC, before the ARPANET was privatized. 
Creation Story \#1 literature of the pre-privatized and feasibility demonstration stage of the ARPANET era is exemplified by literature about cybernetics written for a rather specialized readership. Post-privatization Creation Story \#1 literature is oriented for general readership and is optimistic about networks, until after the Snowden leaks, at which point some literature addresses counterinsurgency issues of surveillance states. But the literature overlooks the pre-privatized, feasibility demonstration stage of the ARPANET as a founding factor for predictive software and modern surveillance states.

Creation Story \#2 pre-privatized, feasibility demonstration stage literature is not focused on the ARPANET so much as on the way the ARPANET was used to prove its feasibility for service mission or privatization. Much of this history is classified or secret, but there is literature documenting that the ARPANET processed massive data for the IC long before it was privatized. To understand this history and how it informs the way the privatized Internet is used today entails examining literature that reports in second-hand fashion what the ARPANET was being used for prior to privatization. This literature reflects issues society has with surveillance (either by human or electronic spying) in the form of legal reports, government reports, protest literature and books about IC abuses. This literature documents in an indirect way how the ARPANET was demonstrating its feasibility to process surveillance data.

In contrast, the post-privatized Creation Story \#2 literature shifts from second-hand or indirect reporting, over to direct reporting, after privatization and after Edward Snowden leaked National Security Administration (NSA) documents in 2013. For example, in 1996, Edwards wrote about Godel's counterinsurgency R\&D, (which was used in developing the ARPANET) in the opening pages of The Closed World: Computers and the Politics of Discourse in Cold War America (1996). And same year, Thomas and Keith published reporter Casolaro's disturbing investigative research about PROMIS software, which was stolen, corrupted and marketed during the feasibility demonstration and pre-privatization years of the ARPANET. Later in the 1990s and 2000s, as corporate tele-com industries usurped the function of government IC personal, more reporting about IC and its' relationship to the ARPANET turned Internet, was published (O'Harrow 2005; Shorrock 2008; Bamford 2009; Harris 2010, 2014; Greenwald 2014; Levine 2018) As of this writing, Edward Snowden's autobiography Permanent Record (2019) contrasts markedly from the second-hand literature, as a highly personal, revealing, first-hand account of how two generations of an IC service family perceived and experienced living through the feasibility demonstration years of the pre-privatized ARPANET and into the Internet era. Creation Story \#2 literature begins with literature that "gets at" the secret IC ARPANET relationship in distant and second-hand ways, but after privatization, it shifts radically to direct reporting about IC abuses and discussions about the historical relationship of the IC to the ARPANET turned Internet.

Pre- privatization, Creation Story \#1 literature is exemplified by the publications of cybernetic scientists such as Norbert Wiener, John von Neumann and J.C.R. Licklider (Jacobsen, 2015). Wiener published Cybernetics: Or Control and Communication in the Animal and Machine (1948) a foundational text in cybernetics. Wiener argues language is uniquely human and a bridge between humans and machines. By 1950 Wiener was having some reservations about a cyber age and he authored, The Human Use of Human Beings. This book warns about the consequences of people thinking they can: keep scientific secrets secret; own information; control how inventions are used by opportunists (including detectives) as a means against other people; and use computers to evade responsibility for their own decision-making. Wiener is the only author whose books appear in both the Creation Story\#1 and \#2 literature because his first book is a foundational text that furthers ARPANET science, while the second book takes a critical perspective of the second-hand, indirect or behind-the-scenes, use and abuse of science, by politicians, capitalists, the military, including investigative agents (Wiener 1954, 185-89). Sixty-five years later Jacobsen's The Pentagon's Brain (also listed in Creation Story \#2 literature) echo's Wiener's concerns when she writes, "Is the world transforming into a war zone and America a police state, and is it DARPA that is making them so? " $(2015,401)$

Licklider authored "Man Computer Symbiosis" (1960) which represents Lick's inspiration for interactive computing. It exemplifies pre-privatized ARPANET literature because it visions computer technology as a neutral aid to humans for: making decisions; making solutions to problems; and aiding in averting problems related to Communism for national security. Lick considered interactive computing as neutral, scientific and beneficial to humankind and other Creation Story \#1 literature took a similar or even more utopian stance. For example, Stewart Brand's The Whole Earth Catalog (1971) promoted ideas about personal computing in a more idealistic or utopian way than Lick's scientifically neutral approach. The Catalog and other literature of a more "California ideology" persuasion, characterized personal computers and the Internet as tools of liberation (Brand 1971; Barbrook \& Cameron, 2015; Turner 2006) rather than weapons of pacification. Neither Lick nor Brand engaged in much discussion about how interactive computers or personal computers 
or the ARPANET that connects them, are used by the military and IC, since these tools are for liberation and are neutral (Levine 2018, 70-1; Foer 11-31).

Another example of a pre-privatized, feasibility demonstration stage, ARPANET into Internet, Creation Story \#1 literature is The Brain of the Firm (1972) by Stafford Beer. Beer was a British cybernetics scientist who designed Project Cybersyn, a computer network for Chilean countrywide economic coordination (destroyed in the CIA assisted coup in 1973). Beer was optimistic that computer networks could help society regulate and coordinate their productive forces for the benefit of the whole society. Cybersyn's operation room had chairs in a circle, where a team of people can face each other (without screens in front of their faces) allowing them to have discussions about information projected onto screens on walls, which they view together. In this way people are not facing individual screens, with different information on each screen. Cybersyn represents a socialized, group decision-making process, aided with real time telecommunications and networks. Beers' books are representative of the pre-privatized network or ARPANET literature that visions networked society as benefited by computerization and shared information; and doesn't dwell on how the networks could be or were being, used for surveillance of citizens by the military.

To understand the working relationship between the military IC and the ARPANET consider the literature listed in the right-hand column under Creation Story \#2 during the pre-privatized, feasibility demonstration stage of the ARPANET. This literature reflects what some people saw as problems created by computers. In 1968 students protested against Lick's, "Project CAM" related computer R\&D because they thought their taxes were being spent on computers that would be used to control society. They didn't see computer technology as neutral, helpful and beneficial to humankind. They published a pamphlet tiled The Cambridge Project: Social Science for Social Control that proclaimed computers were being built to use data for programing society. One booklet alluded to how the computer was like an octopus with arms reaching out into society, with agents using computers to collect more facts to solve more problems (Levine 2018, 64; Rohde 2013b). This protest literature sees fallacy and danger in believing computers are neutral and able to solve human problems and expresses public concerns regarding the relationship between computers, the ARPANET and the IC.

Pre-privatization, feasibility demonstration stage, Creation Story \#2 literature includes government records about the abuses of the IC during the 1960s and 70s. Studies were done for the President, Congress and Senate because the IC was engaged in widespread, domestic, aggressive, spy operations that were illegal, unconstitutional and causing liability problems for the government. Corroborating literature by scholars, journalists and lawyers agree the IC was collecting massive amounts of data on US dissidents (anti-war, anti-draft, anti-military R \& D, pro-Civil Rights and so forth) and processing the data in computers, banking the data and sharing it with different members of the IC network (US Senate 1973; US Senate 1976 a, b, c, d, e, f). The government was concerned about how the IC was doing its' job; but what was happening to the personal information about Americans, which the IC was data banking, was a process that never ended. This literature documents, in a second-hand way, the relationship between the IC and the ARPANET as a military invention in test mode (but not yet privatized into the Internet). The ARPANET demonstrated its feasibility by processing information about Americans gathered through 1960s spy operations. Government reports about IC abuses confirmed massive spy data was collected illegally and unconstitutionally. The IC, the military and the ARPA scientists had a monopoly on the ARPANET so they had control over a hiding place for potentially libelous banked data, similar to how electronic surveillance methods used in the 1940s had been secreted through the FBI's so-called JUNE system (Churchill and Vander Wall 1990, 90, 392n4). By the 1970s government regulators like Schlesinger saw human mismanagement and covert spies as problematic and "spies in the skies" as a ubiquitous and economical solution (Moran 2017, 115).

Also among the pre-privatized, ,feasibility demonstration, pre-1995 ARPANET literature are: The Age of Surveillance (Donner 1981);,The Lawless State: The Crimes of the U.S. Intelligence Agencies (Halperin's et.al 1976); Agents of Repression: The FBI's Secret Wars Against the Black Panther Party and the American Indian Movement (Churchill \& Vander Wall, 1990); and the famous Church Committee reports (US 1976 a-f). These books chronicle surveillance of socalled Un-Americans by human IC spies, assisted by computers. They all report how domestic IC counterintelligence and counterinsurgency CIA and FBI programs collected too much personal information from Americans' deemed Communists or New Left. Donner reports how data gathered by these spy operations became problematic to the justice system. These books confirm that 1960s surplus spy data was creating demand-pull for interactive ARPANET style computers to process data (Packard 2020). Although these books are not about the ARPANET per say, they exemplify Creation Story \#2 literature because they validate in a second-hand way that the IC needed the computers Lick wanted to supply. Those computers made up the ARPANET, which was being demonstrated for feasibility in processing intelligence data (a necessary pre-condition for privatization). 


\subsection{Comparing Post-Privatized Internet Creation Story \#1 and \#2 Literature}

After the ARPANET was privatized and divided between the Internet and MILNET and other IC networks, a lot of popular Creation Story \#1 literature was published. The literature offers the public a rather idealistic view of personal computing and the Internet as a tool for individual liberation from the regulated institutions of society. Electronic tools free people to communicate and do business, education, politics and entertainment, in global ways, with little acknowledgement or discussion about how this technology was demonstrated for its feasibility or funded. Naughton's A Brief History of the Future: the Origins of the Internet exemplifies popular Creation Story \#1 literature. Naughton, like Beer is optimistic about the Internet but for different reasons. Naughton describes network benefits accruing to individuals through personal computing, unlike Beer who visions benefits accruing to society through team-worked coordination of a national economy with help from computerized networks. Whereas Beer writes for computer engineers and government managers, Naughton writes for the general public who will be consumers of personal computing, cell phones and Internet services. Naughton's book is like other post-privatized ARPANET Creation Story \#1 literature (such as Hafner and Lyon's When Wizards Stay Up Late or Markoff's What the Dormouse Said) because it tells a creation story about the post-privatized Internet and personal computing, that is written for general readers, is optimistic about personal computing and wants to inform the public about the Internet but, overlooks ARPANET into Internet history about how the military and IC used and use the ARPANET backbone.

The events of 9/11 2001 ushered in the Patriot Act, mandating tele-com industries to databank customers electronic data so the military can monitor metadata. In 2013 Edward Snowden confirmed the NSA and other agencies lawlessly spy on people through the Internet. At this point Creation Story \#1 literature loses its' optimistic stance regarding personal computing and the Internet. In 2015 Jeff Halper (who living with his wife Shoshana, formerly administered the Israel Committee Against House Demolitions) authored War Against the People: Israel, the Palestinians and Global Pacification (2015). Halper explains how Israel's military, with US support, uses Palestine as a testing grounds to demonstrate feasibility of its' military surveillance and counterinsurgency weapons (which depend on ARPANET style networks) (146). The book's Introduction is titled "How Does Israel Get Away With It?" and Halper gives "on the ground" answers but doesn't delve into ARPANET feasibility demonstration history. Four years later, Harvard Professor, Shoshana Zuboff published The Age of Surveillance Capitalism, which posits the Internet and its corporate managers are using AI and data-banking to make predictions about people and modify behavior. Like Halper, Zuboff's book asks repeatedly "How do they get away with it?"; her answer is more theory based and also excludes early ARPANET history. Zuboff's and Halper's books are listed in the post-privatized Creation Story \#1 literature because they discuss how ARPANET style networks are used against people (like counterinsurgency weapons), but don't relate or root this activity to the 1960s and 70s feasibility demonstration history of the pre-privatized ARPANET, which established the networks that enable the counter-insurgency activity the authors write about.

Moving into the post-privatization part of the Creation Story \#2 Literature column there is Levine's Surveillance Valley: The Secret Military History of the Internet (2018). Levine explains the history of the ARPANET as a combined invention of counterinsurgency research by ARPANET scientists in Vietnam and interactive computer engineering by ARPA scientists in the US. According to Levine, the relationship between the ARPANET and the IC is foundational to the preprivatized ARPANET and to the post-privatized Internet. Levine examines military and civilian ARPANET related history during the same period that Donner's (1981) book examines the legal history. Donner was looking at the human spy operations and its effects on the 1960s, and 70s justice system, while Levine is explaining what was happening with the ARPANET. Levine argues there are three different creation stories for the ARPANET: 1) as a military communication system that survives nuclear attacks; 2 ) as a civilian hacker inspired tool of mythical and personal liberation; 3) and as a counterinsurgency weapon of surveillance $(2018,6-7)$.

Surveillance Valley (2018), posits the ARPANET, turned Internet was born a weapon of counterintelligence and was protested against in the 1960s by people who thought it would be used to manipulate human behavior. On the other hand, Sharon Weinberger's The Imagineer's of War: the Untold Story of DARPA, The Pentagon Agency that Changed the World describes the ARPANET history through the ARPA and Department of Defense (DOD) scientists relationship to ARPA (rather than in relationship to the ARPANET). While Levine reminds readers that 1960 s protestors against military R\&D funding had criticisms about the ARPANET that should still be taken seriously today, Weinberger turns a critical eye on how relevant ARPA's work is for national security today. Weinberger critiques ARPA in way similar to how Schlesinger, of the Office of Management and Budget (OMB) made his critical review of the intelligence community (IC) for President Nixon in 1971. Schlesinger's Report is included in the pre-privatized, feasibility demonstration stage, Creation Story \#2 literature because it acknowledges that communication within the IC is problematic and needs improvement for coordinating, for IC customer needs and quality control. Although Schlesinger doesn't mention computer communication systems, he acknowledges, "technological advances have created new collection possibilities" which may make the old directives obsolete $(1971,4)$. Later when Schlesinger was CIA Director he fired covert spies (some who assisted with the 
coup in Chili) to make way for computer assisted spying (Moran 2017). Weinberger discusses Godel's performance and counterinsurgency R\&D for ARPA in a way similar to how Schlesinger viewed covert spies as problematic. As a national security editor for The Intercept Weinberger makes a critical assessment of ARPA as a generator of expensive science that promotes endless war. Of ARPA, which prides itself on generating defenses for national security and created the world's most expensive counterinsurgency weapon before handing it over to private companies, she writes, "The danger facing the agency today is irrelevance to national security" (365). Unlike Schlesinger's report, Weinberger's The Imagineer's of War (2017) is listed in Creation Story \#1 Literature in the post 9/11 and Post Snowden section because Weinberger denies the IC was using the ARPANET for IC spy data processing in opposition to Ford Rowan's reports about the IC using computer networks (corroborated by government reports). She writes: "None of that is true. Although government agencies were beginning to use elements of computer-networking technology, the ARPANET in 1975 was primarily linking academic institutions" $(2017,305)$.

\section{Summary and Conclusions}

The body of ARPANET/Internet literature shows a division or a gap, between literature that does and does not involve itself with the issue of the working relationship of the IC and the ARPANET/Internet or how ARPA demonstrated the feasibility of the ARPANET to qualify it for privatization. It appears some literature narrows the gap by merging the history of the ARPANET/Internet to the history of its working relationship with the IC and military, while other literature widens the gap by overlooking the IC ARPANET/Internet working relationship or discounting aspects of the available history about the IC relationship with the ARPANET. The Table above lists a sampling of ARPANET/Internet literature and charts the divide in two literary genres titled Creation Story \#1 and \#2. In conclusion it appears Creation Story \#2, pre-privatization and feasibility demonstration stage literature documents in a second-hand or indirect way, how ARPA demonstrated ARPANET's feasibility by processing manually collected intelligence about US citizens; while Creation Story \#2, post-privatization literature documents in a direct way, how tele-communication industries, in conjunction with the IC collect data through the Internet today. Creation Story \#1 literature seems to ignore or refute this IC history or focuses on how todays telecommunication companies engage in covert practices, which originated in pre-privatized ARPANET history (which goes unacknowledged in the literature). Both Creation Story \#1 and \#2 literature shift their orientations; Creation Story \#1 literature becomes less optimistic about the Internet after the Snowden leaks and Creation Story \#2 literature shifts from second-hand to firsthand or direct reporting after privatization and 9/11.

To sum up, in the 1960s Presidents urged the IC to find Communist agitators. The IC collected massive data on Americans which provided: 1) an anti-Communist rationale for continued IPTO/ARPANET funding; 2) a way to make ARPANET feasibility demonstrations, (a necessary pre-condition for either service mission assignment or privatization); and 3) an incentive to expand military, IC and university networks. The ARPANET proved its feasibility as a way to: 1) hide, process, track, store and transfer libelous spy data (putting it into electronic, rather than hard copy form); 2) justify firing covert spy personal; and 3) more economical, ubiquitous and automated spying. These qualities demonstrated: ARPANET's feasibility for privatized service mission. By the early 1970s, military and intelligence agencies connected their networks to the ARPANET and agreed on protocol to share information and coordinate communications with each other through the COINS network (US 1976, 524) This helped meet Schlesinger Report recommendations that the NSA be given authority over signal intelligence to avoid uncoordinated signal intelligence (considered the reason for the failed defense of Pearl Harbor) (Snowden 2019, 2) and that Military Service activities be consolidated as a cost saving measure (US 1971, 41)). The NSA commissioned Licklider's company Bolt, Beranek and Newman (BBN) to build an updated Community Online Intelligence System (COINS) network and a Platform network (Abbate 1999, 134, 234n19; Levine 2018, 92-3, $297 \mathrm{n} 58$ ) which helped to consolidate networked IC activities. The findings confirm that every computerengineering achievement (time-sharing, graphics, high-speed data processing, etc.) that Norberg \& O'Neill, and other authors of Creation Story \#1 literature, like Abbate, Salus, Hafner and Lyons, Waldrop, Naughton or Weinberger describe in their histories of the ARPANET represent: 1) a military operation that rationalized spending taxpayer money on ARPANET R\&D and software projects like CAM, usually in the name of anti-Communism, and 2) resulting feasibility demonstrations that proved ARPANET's effectiveness, secured funding and advertised it to potential mission service sites; or in the case of the NSFNET promoted it as a network ready for (regulated) privatization. The plausibility of this relationship between IPTO, the ARPANET, the IC and the taxpayers who supplied the funding and were spy subjects, seems viable given what is reported in Creation Story \#2 literature.

Still authors disagree over whether the ARPANET was being used to process and distribute IC spy information, when it was demonstrating its feasibility for service mission. For example, in 1975 Ford Rowan a correspondent for NBC Nightly News broadcast that the Federal government was able to build computer files on people and share them with the Pentagon, 
White House and IC. His book TechnoSpies (1978) details how the IC used a computer named HYDRA to databank personal information about thousands of Americans who had simply participated in what they believed was democracy (Rowan 1978, 67; U.S. Senate 1976c695). Other authors confirm the IC was collecting massive data in the 1960s, for example: Morton Halperin, former Deputy Assistant Secretary of Defense and senior staff member of the National Security Council (1976, 135-48); ex-military intelligence Captain Christopher Pyle (1970, 1974); Director of the American Civil Liberties Union Project on Political Surveillance, Frank Donner (1981); Professor Ward Churchill and Vander Wall (1990); and the US government's own reports (US Commission, 1975; US Senate 1973; US Senate 1976a,b, 96-104;c, 689, d, e, f). Years later Weinberger (2017) refutes Rowan's claims, while Levine argues Rowan's claims are verified by a correspondent reporting for ComputerWorld (French 1975) and a report from MIT's The Tech (Sandler \& McNamee 1975). These reports claim the military was using ARPANET to transfer spy data from the NSA at Fort Mead, Maryland to MIT-Harvard for data bank development of surveillance files on American antiwar protestors. In 2019 Harvard Professor Zuboff's The Age of Surveillance Capitalism claims todays' tech industries and surveillance capitalists are collecting personal information on Internet users but she doesn't extend the analysis to the pre-privatized ARPANET, or Project CAM, when Harvard, was helping develop, the computer programing and artificial intelligence that makes the surveillance capitalism Zuboff is writing about, possible today (DOD 1973, 768). Obviously there continues to be a split in the literature that begs consideration of this conclusion: understanding pre-privatization, feasibility demonstration ARPANET history helps to better comprehend literature regarding post-privatization, contemporary Internet counterinsurgency, its methodology and manufactured crises.

By the 1990s networks modeled on the ARPANET were in high demand by the IC, the public and commercial sectors. The government spent nothing on investigating what American taxpayers thought about how the ARPANET would change their lives, but spent millions to build the ARAPNET in secret and spent heavily on public studies to investigate illegal activities of IC spy operations that fed ARPANET people's personal data. In the midst of Reagan's presidency, the ARPANET was privatized; split into the Internet for public and commercial use, with other parts still functioning as networks for the military and the IC. Today the Internet is called an informational- infrastructure but still functions in a counterinsurgency capacity for the IC and military, as whistleblowers, researchers and reporters, have insisted upon for years. Like a human double-agent of yesterday's covert spy operation, the ARPANET forged as a weapon of counterinsurgency in Vietnam and tested on American dissidents, then privatized into the informational infrastructure of the Internet, is an instrument with a split history, function, performance and socially constructed literature trail. The socially constructed literature trail however can be socially re-constructed to close the split described here and if that is done, perhaps the infrastructure's use can be socially re-constructed too.

\section{Acknowledgements}

Thank you to the professors of my four university degree programs, specifically: a BA in Economics, from California State University, Fresno; a Master of Public Administration from California State University East Bay; a MA in Sociology from the New School, NYC and a BA Honors in Sociology from Victoria University of Wellington, New Zealand . These programs made it possible to research and write about this complex subject. Special thanks to Neal Curtis of University of Auckland, Media, Film and Television Department, for encouraging me to publish while in the $\mathrm{PhD}$ program. Thank you all and US Federal Student Loans too.

\section{References}

Abbate, J. (2000). Inventing the Internet. Cambridge, Mass: The MIT Press.

Bamford, J. (2009). The Shadow Factory: The Ultra-Secret NSA from 9/11 to the Eavesdropping on America. New York, N.Y.: Anchor Books.

Barbrook, R., \& Cameron, A. (2015). The California Ideology. Amsterdam: Institute of Network Cultures. Network notebook, No. 10: 12-27. http://www.networkcultures.org/publications

Beer, S. The Managerial Cybernetics of Organization: Brain of the Firm (1981). (2nd ed.). Companion Volume to The Heart of Enterprise. New York, N.Y: John Wiley \& Sons.

Blum, R. H. (1972). Surveillance and Espionage in a Free Society: A Report by the Planning Group on Intelligence and Security to the Policy Council of the Democratic National Committee. New York, N.Y.: Praeger Publishers.

Brand, S. (1971). The Last Whole Earth Catalog. Menlo Park, CA: Nowels Publications.

Churchill, W., \& Wall, V. (1990). Agents of Repression: The FBI's Secret Wars Against the Black Panther Party and the 
American Indian Movement. Boston, MA.: South End Press.

Donner, F. J. (1981). The Age of Surveillance: The Aims and Methods of America's Political Intelligence System. New York: Vintage Books.

Donner, F. J. (1990). Protectors of Privilege. Red Squads and Police Repression in Urban America. Berkeley, CA: University of California Press. https://doi.org/10.1215/01636545-1990-48-5

Edwards, P. N. (1996). The Closed World: Computers and the Politics of Discourse in Cold War America. Cambridge, Mass.: The MIT Press.

Foer, F. (2017). World Without Mind: The Existential Threat of Big Tech. New York: Penguin Press.

French, N. (June 11, 1975). Army Files on Citizens Still Not Destroyed. ComputerWorld. Vol. IX, No. 24. Accessed via University of Auckland library services.

Greenwald, G. (2014). No Place to Hide: Edward Snowden, The NSA, And The U.S. Surveillance State. New York, N.Y.: Metropolitan Books.

Hafner, K., \& M. L. (1996). Where Wizards Stay Up Late: The Origins of the Internet. New York, N.Y: Simon \& Schuster.

Halper, J. (2015). War Against the People: Israel, The Palestinians and Global Pacification. London, UK: Pluto Press. https://doi.org/10.2307/j.ctt183pct7

Halperin, M. H., Berman, J. J., Borosage, R. L., \& Marwick, C. M. (1976) The Lawless State: The Crimes of the U.S. Intelligence Agencies. New York N.Y.: Penguin Books.

Harris, S. (2010). The Watchers: The Rise of America's Surveillance State. New York, N.Y: The Penguin Press.

Harris, S. (2014). @WAR: The Rise of the Military-Internet Complex. New York, N.Y.: Houghton Mifflin Harcourt.

Horowitz, I. L. (ed.) (1974/1967). The Rise and Fall of Project Camelot. Studies in the Relationship between Social Science and Practical Politics. Rev. ed. Cambridge, Massachusetts: The MIT Press.

Jacobsen, A. (2015). The Pentagon's Brain; An Uncensored History of DARPA America's Top-Secret Military Research Agency. New York, N.Y.: Black Bay Books.

Jensen, C. (1997). 20 Years of Censured News. New York: Seven Stories Press.

Johnson, L. K. (May 1990). Review of The Liberals and J. Edgar Hoover: Rise and Fall of Domestic Intelligence State by William W. Keller. The Journal of Politics, Vol. 52, No. 2 University of Chicago Press on behalf of the Southern Political Science Association: 651-654. https://doi.org/10.2307/2131914

Keller, W. W. (1989). The Liberals and J. Edgar Hoover: Rise and Fall of a Domestic Intelligence State. Princeton, N.J.: Princeton University Press. https://doi.org/10.1515/9781400859887

Levine, Y. (2018). Surveillance Valley: The Secret Military History of the Internet. New York, N.Y: Public Affairs.

Lukasik, S. J. (July-Sept 2011). Why the ARPANET Was Built? IEEE Annals of the History of Computing Accessed from University of Auckland. Downloaded from IEEE Xplore. https://doi.org/10.1109/MAHC.2010.11

Markoff, J. (2003). What the Dormouse Said: How the Sixties Counter-Culture Shaped the Personal Computer Industry. New York, N.Y.: Penguin Books.

McChesney, R. W. (1996 Jul/Aug). The Global Struggle for Democratic Communication. Monthly Review. 48(3), ProQuest, (ISSN 0027 0520), 1-20. https://doi.org/10.14452/MR-048-03-1996-07_1

McCoy, A. W. (2009). Policing America's Empire: The United States, the Philippines, and the Rise of the Surveillance State. Madison, Wisconsin: The University of Wisconsin Press.

Mirowski, P. (2002). Machine Dreams: Economics Becomes a Cyborg Science: New York, N.Y: Cambridge University Press.

Monro, N. (Aug 15, 1988). Revamped Arpanet will incorporate T1. Government Computer News, (7)(1), 3. Gale Academic OneFile, com.ezproxy.auckland.ac.nz/apps/doc/A6916523/AONE/u=learn\&sid=AONE\&xid=243f446e

https://link-gale-

Moran, C. (2017). Nixon's Axe Man: CIA Director James R. Schlesinger. Journal of American Studies, 53,1, Cambridge University Press and British Association for American Studies 2017, 95-121. First published online 9 June 2017. https://doi.org/10.1017/S002187581700086X

Moschovitis, C. J. P., Poole, H., Schuyler, T., \& Senft, T. M. (1999). History of the Internet: A Chronology, 1843 to the Present. Santa Barbara, CA: ABC-CLIO. 
Mueller, M. L. (2002). Ruling the Root: Internet Governance and the Taming of Cyberspace. Cambridge, Mass: The MIT Press.

Naughton, J. (2001). A Brief History of the Future: The Origins of the Internet. London, UK: Phoenix.

Norberg, A. L., \& O’Neill, J. E. (1996). Transforming Computer Technology Information Processing for the Pentagon, 1962-1986. Baltimore MD: John Hopkins University Press.

Novak, M. (23 Feb 2015). "A History of Internet Spying. Part 2." Gizmodo Australia. http://www.Gizmodo.com.au/2015/02/a-history-of-internet-spying-part-2/

O’Harrow, Jr., R. (2005). No Place to Hide. New York, N.Y.: Free Press.

Packard, N. (2020). Three Kinds of Demand Pull for the ARPANET into the Internet. Cogent Social Sciences. https://doi.org/10.1080/23311886.2020.1720565

Pyle, C. (1970). CONUS Intelligence: The Army Watches Civilian Politics. Washington Monthly.

Pyle, C. (1974). Military Surveillance of Civilian Politics, 1967-1970. (Unpublished doctoral dissertation) Columbia University, New York, U.S.A.

Rhode, J. (2011). The Last Stand of the Psychocultural Cold Warriors: Military Contract Research in Vietnam. Journal of the History of the Behavioral Sciences, 47(3), 232-250. https://doi.org/10.1002/jhbs.20509

Rhode, J. (2013a). Armed with Expertise: The Militarization of American Social Research During the Cold War. Cornell, N.Y.: Cornell University Press.

Rhode, J. (2013b). "Deeper Shades of Gray: Ambition and Deception in Project Camelot" in Armed with Expertise: The Militarization of American Social Research During the Cold War. Cornell, N.Y.: Cornell University Press

Rowan, F. (1978). Techno Spies. New York: G.P. Putnam's Sons, 1978.

Salus, P. H. (1995). Casting the beyond Net: From ARPANET to INTERNET and beyond. Menlo Park, CA: AddisonWesley Publishing Company.

Sandler, N. D., \& McNamee, M. (April 11, 1975). Computers Carried Army files: MIT investigation underway. The Tech. MIT, Cambridge, Mass.

Schiller, D. (1999). Digital Capitalism: Networking the Global Market System. Cambridge, Mass: The MIT Press. https://doi.org/10.7551/mitpress/2415.001.0001

Shah, R. C., \& Kesan, J. P. (2007). The Privatization of the Internet's Backbone Network. Journal of Broadcasting \& Electronic Media, 51(1), 93-109. https://doi.org/10.1080/08838150701308077

Snowden, E. (2019). Permanent Record. London: MACMILLAN.

Theoharis, A. G. (summer, 1985). The FBI and the American Legion Contact Program, 1940-1966. Political Science Quarterly, 100(2), 271-286. Princeton University Press. https://doi.org/10.2307/2150656

Thomas, K., \& Keith, J. (1996). The Octopus: Secret Government and the Death of Danny Casolaro. Portland, OR: Feral House.

Turner, F. (2006). From Counterculture to Cyberculture: Stewart Brand, the Whole Earth Network, and the Rise of Digital Utopianism. Chicago, Il: The University of Chicago Press. https://doi.org/10.7208/chicago/9780226817439.001.0001

U.S. Commission on CIA Activities Within the United States. (1975). Report to the President. ["Rockefeller Report"]. Washington D.C.: US Government Printing Office. Accessed through University of Auckland library.

U.S. Congress Senate. (1972). Department of Defense. Appropriations for Fiscal Year 1973. Part I. Hearings before a Subcommittee of the Committee on Appropriations. United States Senate. $92^{\text {nd }}$ Congress, Second Session. (February 25.28, March 14, 16, 22-24, 1972); Department of Defense, Advanced Research Projects Agency, Statement of Dr. Stephen J. Lukasik, Director: 725-830, Washington, DC: U.S. Government Printing Office. Retrieved from: https://babel.hathitrust.org/cgi/pt?id=uc1.31210017813393\&view=1 up\&seq=729

U.S. Congress. Senate. (1976). Surveillance Technology. Policy and Implications: An Analysis and Compendium of Materials, A Staff Report of the Subcommittee on Constitutional Rights of the Committee on the Judiciary. United States Senate, 94 ${ }^{\text {th }}$ Congress, 2nd Session. Washington, D.C.: U.S. Government Printing Office. https://hdl.handle.net/2027/uc1.31210015688136

U.S. Congress: Senate. (1976a). Select Committee to Study Governmental Operations, with respect to Intelligence Activities. Final Report. 94 ${ }^{\text {th }}$ Congress, $2^{\text {nd }}$ Session, Book I, Foreign and Military Intelligence, Washington, D.C.: 
U.S. Government Printing $\quad$ Office. $\quad$ Retrieved from https://babel.hathitrust.org/cgi/pt?id=mdp.39015070725273\&view=1up\&seq=3

U.S. Congress: Senate. (1976b). Select Committee to Study Governmental Operations with respect to Intelligence Activities. Final Report. 94 ${ }^{\text {th }}$ Congress, $2^{\text {nd }}$ Session, Book II. Intelligence Activities and Rights of Americans. Washington, D.C.: U.S. Government Printing Office. Retrieved from https://babel.hathitrust.org/cgi/pt?id=uc1.c088719991\&view=1up\&seq=5

U.S. Congress: Senate. (1976c). Select Committee to Study Governmental Operations with Respect to Intelligence Activities. Final Report. $94^{\text {th }}$ Congress, $2^{\text {nd }}$ Session, Book III. Supplementary Detailed Staff Reports on the Intelligence Activities and Rights of Americans. Washington, D.C.: U.S. Government Printing Office.

U.S. Congress: Senate. (1976d). Select Committee to Study Governmental Operations with respect to Intelligence Activities. Final Report. $94^{\text {th }}$ Congress, $2^{\text {nd }}$ Session, Book IV. Supplementary Detailed Staff Reports on Foreign and Military Intelligence. Washington, D.C.: U.S. Government Printing Office. Retrieved from https://babel.hathitrust.org/cgi/pt?id=mdp.39076001702567\&view=1up\&seq=4

U.S. Congress: Senate. (1976e). Select Committee to Study Governmental Operations with respect to Intelligence Activities. Final Report. $94^{\text {th }}$ Congress, $2^{\text {nd }}$ Session, Book V. Investigation of the Assassination of President John F. Kenned: Performance of the Intelligence Agencies. Washington, D.C.: U.S. Government Printing Office.

U.S. Congress: Senate. (1976f) Select Committee to Study Governmental Operations with respect to Intelligence Activities. Final Report. $94^{\text {th }}$ Congress, $2^{\text {nd }}$ Session, Book VI. Supplementary Reports on Intelligence Activities. Washington, D.C.: U.S. Government Printing Office.

U.S. Office of Management \& Budget. (1971). A Review of the Intelligence Community ["Schlesinger Report"]. Washington DC: Office of Management \& Budget. https://nsarchive2.gwu.edu/NSAEBB/NSAEBB144/document\%204.pdf

U.S. Senate. (1973). A Report of Subcommittee on Constitutional Rights, Committee on the Judiciary. $93^{\text {rd }}$ Congress, $1^{\text {st }}$ Session, Military Surveillance of Civilian Politics, Washington D.C.: U.S. Government Printing Office. https://hdl.handle.net/2027/uc1.a0000636795

Waldrop, M. M. (2001). The Dream Machine: J.C.R. Licklider and the Revolution That Made Computing Personal: New York, N.Y.: Viking Penguin.

Weinberger, S. (2017). The Imagineers of War: The Untold Story of DARPA, The Pentagon Agency That Changed the World. New York, N.Y.: Alfred A. Knopf.

Wiener, N. (1949). Cybernetics: Or Control and Communication in the Animal and the Machine. Paris, (Hermann \& Cie) \& Camb. Mass. (MIT Press) ISBN 978-0-262-73009-9; 2nd revised ed. 1961.

Wiener, N. (1950/1954). The Human Use of Human Beings: Cybernetics and Society. DA CAPO Series in Science. New York, N.Y.: DA CAPO Press.

Wilford, H. (2008). The Mighty Wurlitzer: How the CIA Played America. Cambridge, Massachusetts: Harvard University Press.

Zuboff, S. (2019). The Age of Surveillance Capitalism: The Fight for a Human Future at the New Frontier. London, England: Profile Books.

\section{Copyrights}

Copyright for this article is retained by the author(s), with first publication rights granted to the journal.

This is an open-access article distributed under the terms and conditions of the Creative Commons Attribution license which permits unrestricted use, distribution, and reproduction in any medium, provided the original work is properly cited. 